Anna Branach-Kallas*

\section{Rozterki lunatyków. Dlaczego Europejczycy wyruszyli na wojnę sto lat temu według Christophera Clarka}

DOI: http://dx.doi.org/10.12775/LC.2018.040

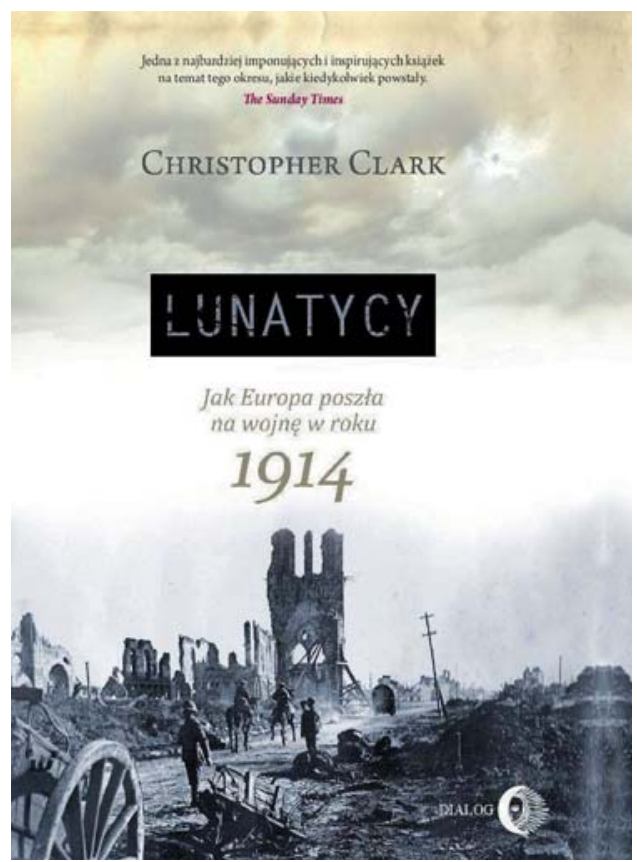

U

znana za arcydzieło rozprawa Christophera Clarka The Sleepwalkers: How Europe Went to War in 1914 z 2012 roku to przełomowe studium przyczyn wybuchu I wojny światowej ${ }^{1}$, które doczekało się właś-

\footnotetext{
* Profesor nadzwyczajny w Katedrze Filologii Angielskiej Uniwersytetu Mikołaja Kopernika w Toruniu.E-mail: kallas@umk.pl.

1 Zob. np. Evans 2013.
}

nie polskiego przekładu², stosunkowo późno $\mathrm{w}$ porównaniu $\mathrm{z}$ innymi krajami ${ }^{3}$. Tym bardziej doceniam wysiłek Wydawnictwa Akademickiego Dialog i Fundacji Centrum im. Profesora Bronisława Geremka, dzięki któremu i polski czytelnik może zapoznać się z tą ważną książką. Clark, australijski badacz Prus i Niemiec, wykłada historię nowożytnej Europy na Uniwersytecie w Cambridge. Warto się zastanowić, co wyróżnia jego dzieło na tle niezliczonych publikacji na temat I wojny, które ukazały się w stulecie konfliktu.

Najbardziej uderzającym aspektem Lunatyków jest bez wątpienia sposób, w jaki Clark kwestionuje ogólnie przyjęte przekonanie o odpowiedzialności Niemiec za wybuch I wojny światowej. Wszak artykuł 231 traktatu wersalskiego wskazał Rzeszę Niemiecką jako głównego winowajcę, a krzywdzące reperkusje, którym poddano w następstwie wojny naród niemiecki, zostały później wykorzystane przez nazistowską propagandę. Clark podważa tym samym słynną tezę Fritza Fischera $\mathrm{z}$ lat sześćdziesiątych ubiegłego wieku, zgodnie z którą to Niemcy i ich sojusznicy rozpętali pierwszy globalny konflikt, dążąc do dominacji w Europie i uzyskania rangi potęgi na arenie międzynarodowej (Clark 2017: 593; Stevenson 2005). Z tego punktu widzenia katastrofa lat 1914-1918 jawi się jako preludium II wojny lub jako początek trzydziestoletniego konfliktu (Winter and Prost 2005: 15-22). W wywiadzie przeprowadzonym na łamach „Kultury Liberalnej” australijski historyk zaznacza, że jego zamiarem nie były tezy rewizjonistyczne, lecz pragnął „stworzyć o wiele bardziej zrówno-

2 Lunatycy. Jak Europa poszła na wojnę w roku 1914 (por. Clark 2017).

3 Przekłady na niemiecki i francuski ukazały się już w 2013 roku. Zob. Die Schlafwandler. Wie Europa in den Ersten Weltkrieg zog, München; Les Somnambules. Été 1914: Comment l'Europe a marché vers la guerre, Paris. 
ważoną koncepcję odpowiedzialności za to, do czego doszło w 1914 r." (Clark 2014)4. W swej rozprawie Clark bynajmniej nie „wybiela” Niemców, ukazując ich aspiracje militarne, imperialne i gospodarcze, podkreśla jednak, iż „[k]ryzys, który przyniósł wojnę w 1914 roku, był owocem w s pólnej kultury politycznej" Europejczyków (Clark 2017: 595; moje podkreślenie).

Clark w sposób niezwykle klarowny i interesujący omawia zagmatwany krajobraz polityczny przełomu XIX i XX wieku, skomplikowane relacje między najważniejszymi aktorami konfliktu, do których zalicza Niemcy, Austro-Węgry, Francję, Wielką Brytanię i Rosję, oraz ich interakcje z szeregiem innych strategicznie istotnych graczy, takich jak Imperium Osmańskie i państwa Półwyspu Bałkańskiego. Fascynującym aspektem Lunatyków jest jednak również usytuowanie polaryzacji Europy w przededniu I wojny $\mathrm{w}$ kontekście przemian globalnych. W tym świetle jedną z przyczyn wybuchu konfliktu był kryzys imperialny. Choć priorytetem polityki zagranicznej Niemiec ery Bismarcka było wykorzystanie rywalizacji Wielkiej Brytanii, Francji i Rosji o podział łupów w Afryce, Azji Środkowej i Chinach dla własnych celów, aspiracje niemieckie do roli światowego mocarstwa zmieniły tę równowagę. Nawet skromne próby ekspansji kolonialnej Niemiec napotkały silny opór mocarstw kolonialnych. $\mathrm{Na}$ wahania polityczne w Europie miały wplyw także inne, pozornie odległe czynniki, takie jak rosnąca rola Japonii jako mocarstwa regionalnego, napięta sytuacja w Chinach czy

\footnotetext{
${ }^{4}$ Clark zaznacza tu również, iż bynajmniej nie dąży do debaty nad odpowiedzialnością Niemców za wybuch II wojny światowej. Ponadto podkreśla, że „polityka Niemiec z okresu I wojny światowej - masowe deportacje w północnej Francji, Belgii i przymusowe obrazy pracy - ukształtowały w znacznej mierze ich późniejsze zachowanie".
}

słabnąca pozycja Imperium Osmańskiego (ibid.: 165-185).

Omawiając klimat polityczny w Europie na przełomie XIX i XX wieku, Clark zaznacza, że jedynie we Francji panowały wówczas silne nastroje antyniemieckie. Niespodziewana klęska Francji w wojnie $\mathrm{z}$ lat 1870-1871 oraz aneksja Alzacji i Lotaryngii przez Niemcy wywołała głęboki kryzys w kulturze i świadomości narodowej Francuzów, który na trwałe odmienił relacje francusko-niemieckie. Kult revanche sprawił, iż Francja z dużą determinacją poszukiwała sojuszników, aby powstrzymać rozwój groźnej potęgi na swej wschodniej granicy (ibid.: 148). Jednakże dla Wielkiej Brytanii, zdaniem Clarka, to Rosja była głównym zagrożeniem, ze względu na jej agresywną ekspansję na kontynencie azjatyckim (ibid.: 161). I tak np., gdy dla Francuzów celem entente cordiale z 1904 roku było budowanie antyniemieckiego sojuszu, z perspektywy brytyjskiej układ ten miał raczej umożliwić wywieranie pośredniego nacisku na Rosję. Obawy Anglików wzbudzał nadzwyczaj dynamiczny wzrost gospodarczy Rzeszy ${ }^{5}$, irytowały ich sytuacje, gdy Niemcy występowały przeciwko nim wraz z Rosją i Francją, lecz Wielka Brytania nie postrzegała ich jako bezpośredniego zagrożenia militarnego. Z punktu widzenia Rosjan Niemcy wspierały z kolei austriackie interesy na Bałkanach, co kolidowało z ich dążeniem do „opieki nad bałkańskimi Słowianami”, dla Rosji najważniejszy był jednak plan przejęcia kontroli nad cieśninami Bosforu, co umożliwiłoby jej dostęp do Morza Śródziemnego. Clark odkrywa tajemne plany sojuszników, ich ukryte cele i nadzieje, lecz również nieumiejętność odczytania wzajemnych intencji -

\footnotetext{
5 „[W] latach 1860-1913 udział Niemiec W światowej produkcji przemysłowej wzrósł czterokrotnie, podczas gdy brytyjski spadł o jedną trzecią", co stanowiło niedwuznaczny sygnał kresu brytyjskiej dominacji na świecie (Clark 2017: 191).
} 
zarówno sprzymierzeńców, jak i potencjalnych wrogów. Niekonsekwentne działania monarchów, nikczemne rywalizacje między mężami stanu, ostre nagonki radykalnej prasy, rosnąca rola armii mocarstw europejskich - to tylko nieliczne z czynników, które sprawiły, że początek XX wieku był okresem „bezprecedensowej niepewności w stosunkach międzynarodowych" (ibid.: 265).

Chaos, który zapanował w Europie po morderstwie w Sarajewie, wynikał w dużej mierze ze wspomnianego braku komunikacji. Podczas gdy Francja oczekiwała natychmiastowego wsparcia od Wielkiej Brytanii, powołując się na entente cordiale, Anglicy byli bardziej zajęci problemem home rule w Irlandii i ewentualnej wojny domowej. Clark opisuje zmieniającą się z dnia na dzień i z godziny na godzinę sytuację polityczną niczym powieściopisarz lub reporter. Podczas gdy 1 sierpnia 1914 roku gabinet Edwarda Greya odmówił wysłania korpusu ekspedycyjnego na kontynent, argumentując, iż „interesy brytyjskie nie były zamieszane w ten konflikt na tyle mocno", żeby to usprawiedliwić (ibid.: 574), 4 sierpnia wypowiedział wojnę Niemcom. Porzucenie decyzji o neutralności na rzecz interwencji przyspieszyły, zdaniem Clarka, obawy przed upadkiem liberalnego rządu, a także nadzieja na odłożenie w czasie kwestii autonomii Irlandii ze względu na konieczność skupienia się na walce zbrojnej z Niemcami. Jednak zaangażowanie $\mathrm{w}$ konflikt po stronie ententy jednocześnie umożliwiło Brytyjczykom „udobruchanie i związanie ze sobą Rosji” (ibid.: 580), co stanowiło dla nich priorytet. W konsekwencji, po przystąpieniu do konfliktu Wielkiej Brytanii, a zatem i krajów Imperium, „trzecia wojna bałkańska” przyjęła globalne rozmiary (ibid.: 267).

Portret Półwyspu Bałkańskiego jest w rozprawie Clarka ciekawy i bardzo złożony. Autor rozpoczyna swe rozważania na temat „dróg”, które doprowadziły do Sarajewa, barwną opowieścią o zamordowaniu pary królewskiej w Belgradzie w 1903 roku, czyniąc $\mathrm{z}$ tego aktu przemocy brutalne wprowadzenie do niestabilnej sytuacji politycznej regionu. Omawia wizjonerski nacjonalizm Serbów, często niekompatybilny ze złożoną strukturą etniczną Bałkanów, mitologizację Wielkiej Serbii oraz nieokreśloność jej granic. To właśnie wyobrażeniowy charakter Wielkiej Serbii jest tu szczególnie fascynujący: „gdzie dokładnie miał się rozpocząć ten proces »odzyskiwania « jej terenów? Czy od Wojwodiny, która znajdowała się wówczas w granicach Królestwa Węgier? Czy od Bośni, która nigdy nie była częścią carstwa Duszana, ale była zamieszkana przez liczną ludność serbską? Czy od leżącej na południu Macedonii, która nadal znajdowała się pod panowaniem tureckim?" (ibid.: 46-47). Badacz ukazuje również skomplikowane relacje polityczne z AustroWęgrami oraz uzależnienie gospodarcze Serbów od potężnego sąsiada. Niczym detektyw lub autor powieści kryminalnej relacjonuje eskalację konfliktu, organizację siatek Czarnej Ręki, Ujedinjenje ili smrt! i Narodnej Obrany. To właśnie z tych grup wywodzili się młodzi bośniaccy zamachowcy, gotowi na męczeńską śmierć po odbyciu szkolenia w Belgradzie. Mimo braku wiarygodnych źródel, celowego zatajania śladów oraz sprzecznych wersji wydarzeń, sam spisek, a także przeprowadzone po zamachu śledztwo, zostały w Lunatykach precyzyjnie odtworzone.

Austro-Węgry natomiast przedstawia Clark jako dysfunkcjonalne, wewnętrznie niespójne „imperium bez właściwości”, które w oczach wielu krajów europejskich było skazane na upadek i niezdolne do obrony swych interesów. Co istotne, badacz zaznacza jednak, że tuż przed wybuchem wojny monarchia dualistyczna stała się jedną z najbardziej dynamicznie rozwijających się gospodarek w Europie, a „odsetek ludności 
z wykształceniem podstawowym przekroczył ten w Niemczech, Francji, Włoszech i Rosji” (ibid.: 94). Clark nie gloryfikuje Austro-Węgier, lecz stara się ocenić politykę mocarstwa w porównaniu do innych praktyk imperialnych przełomu wieków. Po aneksji Bośni i Hercegowiny w 1908 roku administracja austriacka próbowała i w tym regionie zwiększyć wydajność rolnictwa oraz przemysłu. Argument, iż to niesprawne zarządzanie prowincją oraz ucisk jej mieszkańców „popchnął bośniackich Serbów w ramiona Belgradu” (ibid.: 98), jest zdaniem Clarka przesadzony. Historyk twierdzi, że choć wszelkie próby agitacji przeciwko monarchii habsburskiej poddawano surowym represjom, „[o]gólnie rzecz biorąc, była to $[. .$.$] względnie sprawiedliwa$ i efektywna administracja oparta na pragmatycznym szacunku dla różnorodności tradycji narodów zamieszkujących te prowincje" (ibid.: 101). Przyczyny zamachu dopatruje się raczej $\mathrm{w}$ ultranacjonalistycznych aspiracjach Serbów. Po zabójstwie pary królewskiej w 1903 roku władzę w Belgradzie przejęli politycy niekryjący wrogości wobec monarchii austro-węgierskiej, a nastroje te usiłowała wykorzystać Rosja. Po wojnach bałkańskich terytorium Serbii powiększyło się o osiemdziesiąt procent, co osłabiło pozycję Austrii na Półwyspie Bałkańskim. Być może zbyt późno rząd habsburski zaczął się liczyć z rosnącym w potęgę Belgradem (ibid.: 105-125). Clark podkreśla, że arcyksiążę Franciszek Ferdynand nie został zamordowany ze względu na swoją niechęć do ludności słowiańskiej zamieszkałej w monarchii austro-węgierskiej, lecz wręcz przeciwnie, ze względu na swe rzekome plany reformatorskie, które miały zwiększyć autonomię mniejszości etnicznych, co w oczach serbskiej irredenty stanowiło zagrożenie dla jej projektu zjednoczeniowego (ibid.: 73). Choć zabójstwo mało popularnego następcy tronu nie wywołało wielkich emocji w cesarstwie, miało olbrzymie znaczenie polityczne, gdyż stanowiło cios w reformy monarchii, przyszłość dynastii panującej i samego imperium.

Szczególnie ciekawe i nowatorskie są również porównania Clarka do mniej oddalonych czasowo realiów, które pozwalają czytelnikowi lepiej zrozumieć kontekst historyczny sprzed stu lat ${ }^{6}$. Najistotniejsze są tu analogie między kryzysem lipcowym a dzisiejszą sytuacją w Europie. Trzech zamachowców samobójców, których czyny miały odmienić losy świata, badacz porównuje do naiwnych idealistów wykorzystywanych przez współczesne siatki terrorystyczne. Cechami charakterystycznymi takich organizacji są kult zemsty i śmierci, komórki umiejscowione w różnych krajach oraz niejasne powiązania $\mathrm{z}$ agendami rządowymi. Zamach na arcyksięcia stanowi w tym świetle przykład logiki ruchów terrorystycznych, zgodnie z którą reformatorzy są groźniejsi od zaciekłych dogmatyków (ibid.: 73-74). Ponadto, zdaniem Clarka, nieprzewidywalny układ sił powstały w Europie po upadku ZSRR sprawia, że skomplikowana sytuacja w przededniu wojny jest dla nas obecnie bardziej czytelna, co skłania do przemyślenia na nowo okoliczności, które sto lat temu skłoniły Europejczyków do działań zbrojnych (ibid.: 20). Chaos lipca 1914 roku nasuwa badaczowi także skojarzenia z kryzysem finansowym strefy euro w latach 2011-2012, lecz podczas gdy ten ostatni próbowały wspólnie zażegnać rządy wielu krajów, przed stu laty nie istniały instytucje pośredniczące $\mathrm{w}$ rozwiązywaniu konfliktów międzynarodowych, a „głębokie rozdarcie etycznych i politycznych punktów widzenia podkopywało konsensus i nadwątlało zaufanie" (ibid.: 598). Choć wielu polityków zdawało sobie sprawę, że wojna

6 Zob. Cullen 2014. Na temat ryzyka uproszczeń, jakie niosą za sobą takie porównania, zob. Clark 2014. 
nie zakończy się przed świętami Bożego Narodzenia, „uczestnicy wydarzeń z roku 1914 byli lunatykami mającymi się na baczności, ale niewidzącymi, nawiedzanymi przez złe sny, ale ślepymi na rzeczywistość tego koszmaru, jaki sprowadzali na świat" (ibid.: 596).

Rozczarowuje nieco w dziele Clarka brak refleksji kulturoznawczej, której można by się spodziewać po uczniu Jaya $M$. Wintera, współtwórcy historii kulturowej Wielkiej Wojny. Z wyjątkiem zwięzłych rozważań na temat kryzysu męskości $\mathrm{w}$ przededniu wybuchu konfliktu, autor ogranicza się do powierzchownych anegdot, opisując życie intymne głów państw, polityków i dyplomatów. W tym sensie, jak twierdzi Hubert Czyżewski, Lunatycy to „historia high politics w starym stylu, opowieść o elitach grających $\mathrm{w}$ pokera o losy świata. [...] Autor tak bardzo skupia się na opisaniu, jak konkretni ludzie doprowadzili do wojny, że zapomina przedstawić kontekst, w którym ci ludzie funkcjonowali i z którego wyrośli, a który zdeterminował przecież ich światopoglądy i określone podejście do rzeczywistości” (Czyżewski 2014). Polemika Clarka z tezą Fischera może wydawać się etycznie kontrowersyjna również ze względu na konieczność jasnego określenia ofiar i sprawców traumatycznych wydarzeń, co jest charakterystyczne dla dyskursów upamiętniania (Alexander 2010: 208). Nowatorskie, wolne od germanofobii ujęcie przyczyn konfliktu w Lunatykach pozwala jednak również zrozumieć, jak wykształcily się „ramy” poznawcze wojny, które wyznaczały polityczną i moralną ocenę działań wojennych? ${ }^{7} \mathrm{~W}$ pierwszej fazie aktywności zbrojnej propaganda aliancka przedstawiała bowiem Niemców jako wyru-

7 Zdaniem Judith Butler (2011) nasze podejście do wojny i reakcje emocjonalne na związane z nią ludzkie cierpienie wyznaczają pewne "ramy", oparte na przekazie dyskursywnym i medialnym. szających na podbój Europy barbarzyńców, lubującą się w okrucieństwach bestialską rasę podludzi (Cooperman 1967: 23-24; Audoin-Rouzeau and Becker 2014: 154). Hiperboliczny obraz demonicznego wroga pojawia się również w literaturze wojennej, która w dużej mierze ukształtowała uproszczone wyobrażenia o froncie zachodnim (Fussell 1975: 75-77).

Rekonstrukcja politycznych motywacji i ambicji sprzed stu lat jest w książce Clarka fascynująca. Wprowadzając ład w gąszczu powiązań, sporów i sojuszy, australijski badacz zwraca jednocześnie uwagę na fakt, iż to z perspektywy czasu często przypadkowe wydarzenia początku XX wieku układają się w logiczną całość. W ten sposób istotne staje się zrozumienie nie tylko tego, jak doszło do wybuchu konfliktu i jakie były jego przyczyny, lecz również tego, że być może nie był on nieunikniony. Po przeczytaniu Lunatyków nie sposób nie zgodzić się z Clarkiem, iż I wojna światowa jest „najbardziej złożonym wydarzeniem czasów współczesnych" (Clark 2017: 595), i łatwiej zrozumieć, dlaczego badania jej przebiegu i przyczyn generują tak liczne debaty i kontrowersje nawet sto lat po tym, jak Gavrilo Princip oddał dwa strzały w Sarajewie.

\section{Bibliografia}

Alexander, Jeffrey C. 2010. Znaczenia spoteczne. Studia $z$ socjologii kulturowej. Tłumaczenie Stanisław Burdziej, Jacek Gądecki. Kraków: Zakład Wydawniczy „Nomos”.

Audoin-Rouzeau, Stéphane and Annette Becker 2014. 14-18: Understanding the Great War. Tlumaczenie Catherine Temerson. New York: Hill and Wang.

Butler, Judith 2011. Ramy wojny: kiedy zycie godne jest optakiwania?. Tłumaczenie Agata Czarnacka. Warszawa: Instytut Wydawniczy Książka i Prasa, Teatr 
Dramatyczny m. st. Warszawy im. Gustawa Holoubka.

Clark, Christopher 2017. Lunatycy. Jak Europa poszta na wojnę w roku 1914. Tłumaczenie Malwina Fiedorek, Tomasz Fiedorek. Warszawa: Wydawnictwo Akademickie DIALOG.

— 2014. „Lunatycy. Christopher Clark w rozmowie z Jarosławem Kuiszem i Karoliną Wigurą". Kultura Liberalna 30 (290, 29 lipca 2014). https://kulturaliberalna. pl/2014/07/29/christopher-clarkrozmowa-pierwsza-wojna-swiatowa/ [15.01.2015].

Cooperman, Stanley 1967. World War I and the American Novel. Baltimore: The John Hopkins Press.

Cullen, Jim 2014. „Review of Christopher Clark's The Sleepwalkers: How Europe Went to War in 1914". History News Network. http://historynewsnetwork. org/article/152847 [10.10.2017].

Czyżewski, Hubert 2014. „Gra o tron 1914. The Sleepwalkers Christophera
Clarka”. Kultura Liberalna 30 (290, 29 lipca 2014). https://kulturaliberalna.pl/2014/07/29/recenzja-the-sleepwalkers-christopher-clark/ [15.01.2015].

Evans, Harold 2013. „On the Brink: The Sleepwalkers and July 1914". The New York Times (9 maja 2013). http:// www.nytimes.com/2013/05/12/ books/review/the-sleepwalkers-andjuly-1914.html [27.08.2013].

Fussell, Paul 1975. The Great War and Modern Memory. New York-London: Oxford University Press.

Stevenson, David 2005. „Grands noms et construction d'une historiographie: l'affaire Fritz Fischer". W: Jean-Jacques Becker (red.). Histoire culturelle de la Grande Guerre. Paris: Armand Colin.

Winter Jay and Antoine Prost 2005. The Great War in History: Debates and Controversies. Cambridge: Cambridge University Press. 